\title{
Identifikasi Karakter Fenotip Daun Tanaman Aren (Arenga pinnata Merr) di Kabupaten Tapanuli Selatan
}

\author{
Identification Phenotypic Character of the Leaves Palm Plant in South Tapanuli Regency
}

Parmanoan Harahap ${ }^{1 *}$, Mahyuni Khairiyah Harahap ${ }^{1}$, Fitra Syawal Harahap ${ }^{2}$

${ }^{1}$ Program Studi Agroteknologi, Fakultas Pertanian Universitas Graha Nusantara Padangsidimpuan, 22718

${ }^{2}$ Program Studi Agroteknologi, Fakultas Sains dan Teknologi Universitas Labuhanbatu

*Corresponding author : parmabona12@gmail.com

\begin{abstract}
Identification Phenotypic Character of the Leaves Palm Plant in South Tapanuli Regency This study aims to determine the effect of the phenotype character of palm leaf leaves on the production of roomie in wild populations of natural habitats in South Tapanuli Regency. The study was conducted in five villages in each oft he four sub-districts in South Tapanuli district. Two hundred sugar palm plants originating from four natural habitats have been identified in accor dance with plant identification procedures issued by the IPGRI (International Plant Genetic Resources Institute, 1995) and analyzed. The results show that 4 clusters were formed with $75 \%$ similarity or $25 \%$ diversity. These results can be concluded that, cluster 1 is the population of palm plants which have the long character of petiole and the highest number of unproductive leaves. Where as the characters of leaf length and rachis length are still lower than the population of sugar palm plants in cluster 4. Cluster 2 is the population of sugar palm plants which has the highest character of sap production per day. Cluster 3 is a population of palm plants that have the highest leaf width character. Cluster 4 is a population of palm plants that have the highest leaf length and rachis length with the highest number of leaflets and the largest rachis circum ference and petiole circum ference. The number of productive leaves and the percent age of sap sugar content above average.
\end{abstract}

Keywords: Arenga pinnata, Leaves, Phenotype, Identification, Character.

\section{ABSTRAK}

Identifikasi Karakter Fenotip Daun Tanaman Aren (Arenga pinnata Merr) di Kabupaten Tapanuli Selatan bertujuan untuk mengetahui pengaruh karakter fenotip daun tanaman aren terhadap produksi nira pada populasi liar habitat alam di Kabupaten Tapanuli Selatan. Penelitian dilaksanakan di lima desa pada masing-masing empat kecamatan di kabupaten Tapanuli Selatan. Dua ratus tanaman aren yang berasal dari empat habitat alam telah di identifikasi sesuai dengan tata cara identifikasi tanaman yang dikeluarkan oleh IPGRI (International Plant Genetic Resources Institute, 1995) lalu dianalisis. Hasil menunjukkan bahwa terbentuk 4 cluster dengan tingkat kemiripan $75 \%$ atau keragaman sebesar $25 \%$. Hasil ini dapat disimpulkan bahwa, cluster 1 merupakan populasi tanaman aren yang memiliki karakter panjang petiole dan jumlah daun tidak produktif paling tinggi. Sedangkan karakter panjang daun dan panjang rachis masih lebih rendah dari populasi tanaman aren di cluster 4. Cluster 2 merupakan populasi tanaman aren yang memiliki karakter produksi nira per hari paling tinggi. Cluster 3 merupakan populasi tanaman aren yang memiliki karakter lebar daun paling tinggi. Cluster 4 merupakan populasi tanaman aren yang memiliki karakter panjang daun dan panjang rachis paling tinggi dengan jumlah anak daun yang paling banyak dan lingkar rachis serta lingkar petiole paling besar. Jumlah daun produktif dan persentase kadar gula nira yang di atas rata-rata.

Kata kunci : Aren, Daun, Fenotip, Identifikasi, Karakter. PENDAHULUAN

Potensi tanaman aren di Kabupaten Tapanuli Selatan sangat besar. Sebaran 
populasi tanaman aren yang tumbuh liar di alam merupakan potensi sumber daya alam lokal yang menjadi peluang bila dikembangkan. Hal ini terbukti bahwa tanaman aren secara turun temurun dimanfaatkan oleh petani sebagai tambahan pendapatan diluar pendapatan pokok.

Luasnya penyebaran populasi serta tingginya keanekaragaman tanaman aren ini mengakibatkan sulit untuk menduga tinggi atau rendahnya produksi nira yang digunakan sebagai bahan dasar pembuatan gula aren. Hal ini terbukti dari hasil penelitian yang dilakukan yaitu, Eksplorasi dan Identifikasi Tanaman Aren di Kabupaten Tapanuli Selatan dengan hasil bahwa karakter daun merupakan karakter yang paling berpengaruh nyata terhadap produksi nira aren (Harahap et al., 2018). Menurut Harahap et al., (2018) ada perilaku petani aren yang termasuk kontra produktif dengan produksi nira, antara lain, petani seolah tidak ada beban untuk memotong daun dengan alasan kemudahannya untuk menyadap atau untuk memudahkan pemanjatan agar tidak terhalang.

Padahal sesuai dengan yang disampaikan Kusmanto D. (2008) dengan berkurangnya daun berarti berkurang juga aktifitas fotosintesa, maka sebenarnya akan berakibat berkurang juga hasil asimilatnya yang antara lain berupa nira. Maka memotong atau mengurangi daun yang masih hijau dan segar berakibat dapat mengurangi produksi nira. Jadi, mengurangi daun yang produktif harus dihindari. Menurut Harahap. M.K (2018) memang terbukti bahwa semakin banyak jumlah daun yang ada pada tanaman aren maka semakin banyak juga nira yang bisa disadap. Semakin sedikit jumlah daun yang produktif pada pohon Aren, maka semakin sedikit juga nira yang diperoleh.

Nira merupakan salah satu produk dari tanaman aren yang banyak dimanfaatkan baik untuk gula dan minuman. Nira mengandung gula antara $10-15 \%$ brix, yang dihasilkan dari tandan bunga baik tandan betina atau jantan
(Hasbullah, 2001). Dalam Lempang, et al., (2012) nira aren mengandung air $(87,66 \%)$, gula $(12,04 \%)$, protein $(0,36 \%)$, lemak $(0,36 \%)$, dan abu $(0,21)$. Nira aren juga mendandung mineral seperti $\mathrm{Fe}, \mathrm{Ca}, \mathrm{Mg}, \mathrm{K}$, $\mathrm{Na}, \mathrm{Cu}$, dan $\mathrm{P}$, dengan kandungan sebesar $1,50 \pm 0,23 \%$.

Tanaman aren sehat setiap tandan bunga jantan dapat memproduksi nira 9001.800 liter/tandan, sedangkan tanaman aren yang pertumbuhannya kurang baik menghasilkan nira rata-rata 300-400 liter/tandan (Lutony, 1993).Tanaman aren mampu menghasilkan 7 L/hari, 4-5 L/Tanaman pada pagi hari dan 2-3 hari pada sore hari (Lempang, et al., 2012). Atas dasar inilah penulis tertarik melakukan penelitian tentang Identifikasi Karakter Fenotip Daun Tanaman Aren yang berproduksi, mulai dari produksi nira terendah hingga produksi nira tertinggi di Kabupaten Tapanuli Selatan. Tujuan penelitian ini adalah untuk mengetahui pengaruh karakter fenotip daun tanaman aren terhadap produksi nira pada populasi liar habitat alam di Kabupaten Tapanuli Selatan.

\section{BAHAN DAN METODE}

Teknik pengumpulan dan analisis data penelitian ini dilakukan dengan metode survei. Dengan cara menjelajah dan mengumpulkan berbagai tanaman aren yang ada di sentra-sentra produksi gula aren pada 5 desa di 4 kecamatan, Kabupaten Tapanuli Selatan. Tahapan dalam penelitian ini dilaksanakan dengan tiga tahap. Tahap pertama adalah survei pengambilan sampel dilakukan secara purposive sampling yaitu teknik pengambilan sampel untuk dijadikan sampel berdasarkan kriteria yang ada setelah mengetahui karakteristik populasinya di sentra-sentra produksi gula aren. Survei ini bertujuan untuk mengetahui daerah sasaran penelitian yang memiliki populasi tanaman aren.

Tahap kedua adalah identifikasi karakter fenotip daun tanaman aren, dilakukan berdasarkan IPGRI 
(International Plant Genetic Resources Institute). Menyusun descriptor list karakter fenotip daun tanaman aren dalam sebuah matriks identifikasi, sehingga memudahkan peneliti dalam mengidentifikasi dan mengukur variabel pada setiap tanaman sampel yang diamati. Tahap ketiga adalah analisis data. Data yang didapatkan dari lapangan digambarkan secara deskriptif. Selanjutnya, dilakukan analisis data dengan analisa statistik untuk melihat kesesuaian data yaitu dengan menggunakan analisis faktor, analisis cluster dilakukan untuk mengetahui sebaran kelompok dan tingkat keragaman, dan analisis korelasi untuk mengetahui variabel mana yang berpengaruh terhadap produksi nira aren.

\section{HASIL DAN PEMBAHASAN}

Tanaman aren yang tersebar pada 20 desa di 4 kecamatan kabupaten tapanuli selatan dibagi dalam 2 sebaran data, yaitu data karakter kualitatif dan terdapat keanekaragaman karakter fenotip daun tanaman aren. Keanekaragaman tersebut dapat dilihat dari 6 karakter daun yang diamati, yaitu arah duduk daun, warna rachis, warna petiole, tepi anak daun, ujung anak daun dan warna anak daun bagian bawah.

Tabel 1. Hasil Identifikasi Data Kualitatif terhadap Keanekaragaman Karakter Fenotip Daun Tanaman Aren

\begin{tabular}{lll}
\hline NO & \multicolumn{1}{c}{ KARAKTER FENOTIP } & \multicolumn{1}{c}{ IDENTIFIKASI } \\
\hline 1. & Arah Duduk Daun & Spiral Kanan \\
& & Spiral Kiri \\
2. & Komposisi Daun & Daun Majemuk \\
3. & Tipe Daun & Majemuk Menyirip \\
4. & Tata Letak Daun & Berpasangan Besilang \\
5. & Bentuk Tangkai Daun & Melengkung \\
6. & Warna Rachis & Hijau Muda \\
& & Hijau Tua \\
7. & Warna Petiole & Abu-abu \\
& & Coklat Abu-abu \\
& & Coklat \\
8. & Bentuk Helaian Anak Daun & Linier Meruncing \\
9. & Pangkal Anak Daun & Meruncing \\
10. & Tepi Anak Daun & Bergerigi \\
& & Bergelombang \\
& & Rata \\
11. & Ujung Anak Daun & Runcing \\
& & Terbelah \\
12. & Permukaan Anak Daun Bagian Atas & Licin Mengkilap \\
13. & Permukaan Anak Daun Bagian Bawah & Berselaput Lilin \\
14. & Warna Anak Daun Bagian Atas & Hijau Tua \\
15. & Warna Anak Daun Bagian Bawah & Abu-abu \\
& & Coklat Abu-abu \\
16. & Warna Nira & Coklat \\
\hline & & Bening \\
\hline
\end{tabular}

1. Cluster 1. Merupakan kelompok populasi tanaman aren yang memiliki kemiripan berdasarkan lokasi tumbuh dan tersebar pada desa Sisundung, Sihuik Kuik, Simarpinggan dan Janji Mauli. 
Jumlah anggota pada cluster 1 yaitu 4 desa.

2. Cluster 2. Merupakan kelompok populasi tanaman aren yang memiliki kemiripan berdasarkan lokasi tumbuh dan tersebar pada desa Sialogo, Aek Nabara, Gapuk Tua, Aek Sabaon, Sugi, Parau Sorat dan Siala Gundi. Jumlah anggota pada cluster 2 yaitu 7 Desa.

3. Cluster 3. Merupakan kelompok populasi tanaman aren yang memiliki kemiripan berdasarkan lokasi tumbuh dan tersebar pada desa Sitara Toit, Lobu Layan Sigordang, Sitinjak, Sibombong, Pintu Padang, Sinyior, Baringin dan Pargarutan. Jumlah anggota pada cluster 3 yaitu 8 Desa.

4. Cluster 4. Merupakan kelompok populasi tanaman aren yang terpisah sendiri dari 3 cluster yang lain yaitu lokasi tumbuh dan tersebar pada desa Hau Natas. Jumlah anggota pada cluster 4 yaitu 1 desa.

\section{Dendrogram using Average Linkage (Between Groups)}

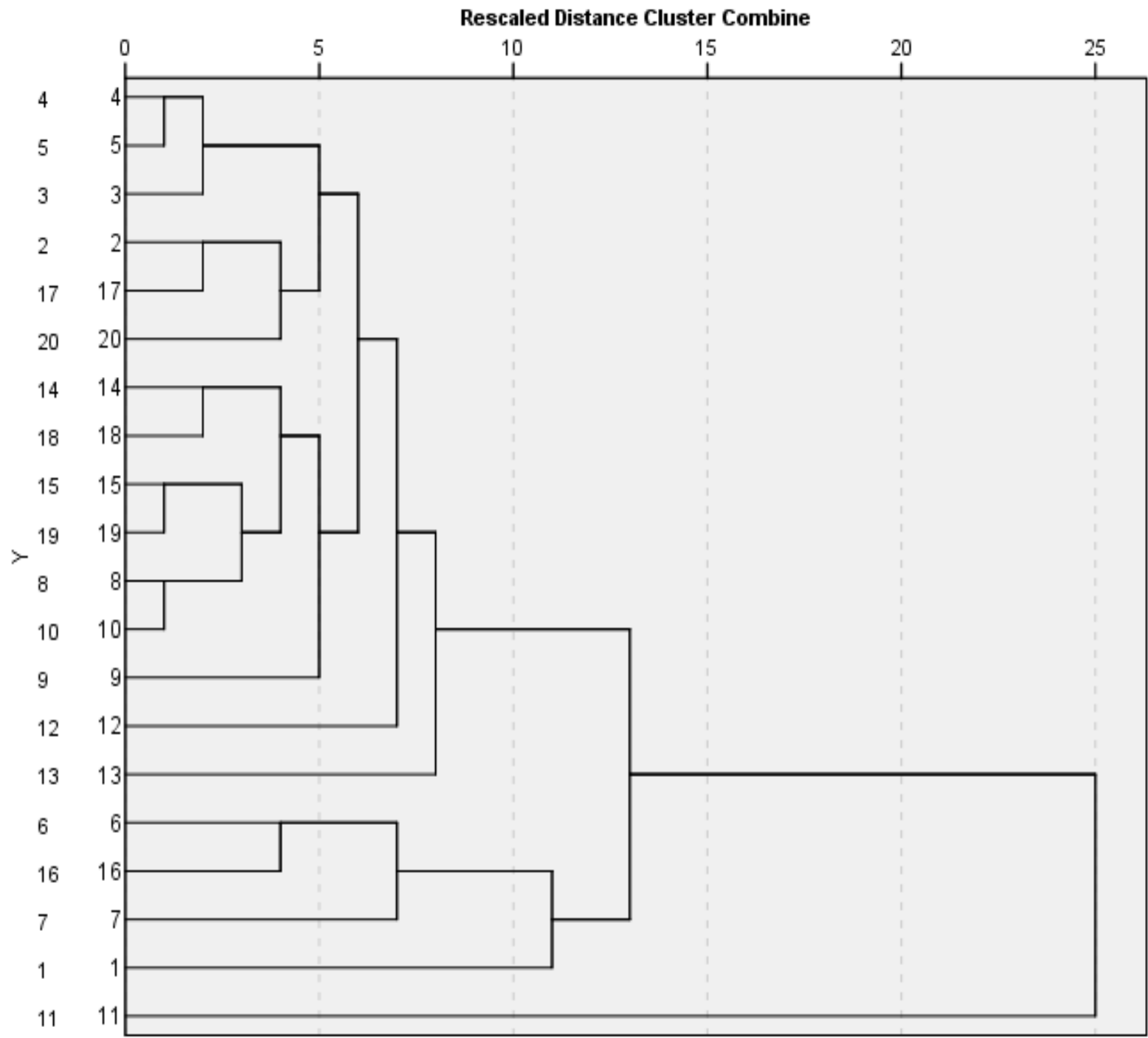

Gambar 1. Dendogram hasil analisis cluster berdasarkan sebaran populasi tiap Desa

Berdasarkan kemiripan dan keragaman karakter fenotip daun tanaman aren pada tiap cluster merupakan populasi tanaman aren liar habitat alam yang tepat untuk memproduksi nira yang tinggi. 
di atas maka dapat disimpulkan :

1. Cluster 1 merupakan populasi tanaman aren liar habitat alam yang memiliki karakter panjang petiole dan jumlah daun tidak produktif paling tinggi. Sedangkan karakter panjang daun dan panjang rachis masih lebih rendah dari populasi tanaman aren di cluster 4 .

2. Cluster 2 merupakan populasi tanaman aren liar habitat alam yang memiliki karakter hasil nira per hari paling tinggi, sehingga dapat disimpulkan populasi tanaman aren liar habitat alam memiliki produksi hasil nira tertinggi.

3. Cluster 3 merupakan populasi tanaman aren liar habitat alam yang memiliki karakter lebar daun paling tinggi.

4. Cluster 4 merupakan populasi tanaman aren liar habitat alam yang memiliki karakter panjang daun dan panjang rachis paling tinggi dengan jumlah anak daun yang paling banyak dan lingkar rachis serta lingkar petiole paling besar. Jumlah daun produktif dan persentase kadar gula nira yang di atas rata-rata.

\section{Simpulan}

Hasil identifikasi karakter fenotip daun tanaman aren dari 200 tanaman sampel yang tersebar di 20 desa pada 4 kecamatan di Kabupaten Tapanuli Selatan terbentuk 4 cluster sesuai dengan kemiripan dan keragaman yang dimiliki. Keempat cluster tersebut memiliki tingkat kemiripan $75 \%$ atau keragaman sebesar $25 \%$. Cluster 2 merupakan populasi tanaman aren liar habitat alam yang memiliki karakter hasil nira per hari paling tinggi, sehingga ciri dan karakter fenotip daun tanaman aren pada cluster 2

\section{DAFTAR PUSTAKA}

Hasbullah. 2001. Teknologi Tepat Guna Agroindustri Kecil Sumatera Barat. Padang. Dewan Ilmu Pengetahuan, Teknologi dan Industri Sumatera Barat.

IPGRI, 1995. Descriptors for Coconut (Cocosnucifera L). International Plant Genetic Resources Institute. Roma. Italy.

http://indoplasma.or.id/deskrip tor.htm.

Kusmanto, D. 2008. Sifat Aren Dan Kiat Kebun Produktif. http://kebunaren.blogspot.com/200 8/08/sifat-aren-dan-kiatkebunproduktif.html.

Lempang, M. dan Mangopang, A.D. Efektivitas Nira Aren Sebagai Bahan engembang Adonan Roti. Jurnal Penelitian Kehutanan Wallacea Vol.1 No.1,Pp : 26-35.

Lutony, 1993. Tanaman Sumber Pemanis. Penebar Swadaya.

Harahap, M. K. 2018. Karakter Daun Dan Produksi Nira Tanaman Aren (Arenga pinnata Merr) Di Kecamatan

Marancar. GrahaTani, 4(1), 587599.

Harahap, P., Rosmayati, R., Harahap, E. M., Harahap, D. E., \& Harahap, F. S. 2018.Eksplorasi dan Identifikasi Tanaman Aren (Arenga pinnata Merr) di Kabupaten Tapanuli Selatan. Jurnal Pertanian Tropik, 5(3, Des), 423-427. 